\title{
DETERMINANTS AND MITIGATION FACTORS OF TAX EVASION : INDONESIA EVIDENCE
}

\author{
Yolisia Framita Agus, Indah Umiyati, Asep Kurniawan \\ Sekolah Tinggi IImu Ekonomi Sutaatmadja, Indonesia \\ yolisframita@gmail.com
}

\begin{tabular}{|c|c|}
\hline INFO ARTIKEL & ABSTRAK/ABSTRACT \\
\hline $\begin{array}{l}\text { Histori Artikel } \\
\text { Tgl. Masuk : : } 28 \text { September } 2019 \\
\text { Tgl. Diterima : } 30 \text { September } 2019 \\
\text { Tersedia Online : } 30 \text { September } 2019 \\
\text { Keywords: } \\
\text { Justice, System, } \\
\text { Understanding, Tariffs, Tax } \\
\text { Sanctions and Tax Evasion }\end{array}$ & $\begin{array}{l}\text { This study aims to determine the effect of justice, system, } \\
\text { understanding, tax rates and sanctions on tax evasion. The } \\
\text { method used in this study is descriptive quantitative by } \\
\text { using primary data. The technique of collecting data with a } \\
\text { questionnaire distributed to corporate taxpayers registered } \\
\text { at Pratama KPP with a sample of } 110 \text { respondents. Data } \\
\text { analysis in this study is multiple regression with SPSS } \\
\text { version } 22 \text { program. }\end{array}$ \\
\hline
\end{tabular}

The results of this study indicate that understanding taxation affects tax evasion. While justice, system, tax rates and sanctions have no effect on tax evasion.

\section{PENDAHULUAN}

Indonesia merupakan negara berkembang yang membutuhkan dana untuk membiayai pembangunan. Dana pembangunan berasal dari berbagai sumber pendapatan negara antara lain : Penerimaan sumber daya alam, Pendapatan bagian laba BUMN dan pendapatan terbesar negara Indonesia berasal dari pendapatan pajak. Pajak dipandang sebagai sumber pendapatan utama dan sangat penting bagi pemerintah pendapatan yang dibutuhkan untuk membiayai program, layanan, dan infrastruktur penting, yang bermanfaat bagi masyarakat. Worlu \& Nkoro (2012) menegaskan bahwa pemanfaatan penerimaan pajak merupakan dasar untuk mendukung kegiatan pembangunan di negara berkembang (Bekoe, NketiahAmponsah, \& Annan, 2018). Menurut UU nomor 28 tahun 2007 tentang ketentuan umum dan tata cara perpajakan pajak adalah kontribusi wajib kepada negara yang terutang oleh orang pribadi atau badan yang bersifat memaksa berdasarkan undang-undang, dengan tidak mendapatkan imbalan secara langsung dan digunakan untuk keperluan Negara bagi sebesar-besarnya kemakmuran rakyat.

Pemerintah Indonesia melakukan berbagai upaya untuk meningkatkan penerimaan pajak dengan melaksanakan reformasi pajak secara konsisten dan berkelanjutan, lalu meningkatkan pelayanan kepada wajib pajak dalam bentuk kemudahan pelaporan, pembayaran, dan kemudahan akses informasi perpajakan, Selanjutnya, pemerintah mengklaim akan meningkatkan efektivitas penyuluhan dan hubungan masyarakat dalam rangka meningkatkan kesadaran dan kepatuhan wajib pajak, meningkatkan ekstensifikasi, intensifikasi, dan penegakan hukum perpajakan, meningkatkan efektivitas pemeriksaan dan penagihan, meningkatkan kapasitas Direktorat Jenderal Pajak (DJP) yang meliputi penguatan sumber daya manusia, 
teknologi informasi, dan anggaran. Serta memanfaatkan hasil kebijakan pengampunan pajak.

Penerimaan dari sektor pajak dari tahun ke tahun mengalami peningkatan namun sampai saat ini pencapaian penerimaan pajak belum memenuhi target yang di tentukan hal ini dapat dilihat dari tabel sebagai berikut :

Tabel 1.1

Realisasi Penerimaan Pajak

\begin{tabular}{|c|r|r|}
\hline Tahun & Target & Realisasi \\
\hline 2014 & $1.072,38$ & 985,13 Triliun \\
& Triliun & \\
\hline 2015 & $1.294,25$ & $1.060,86$ \\
Triliun & Triliun \\
& 1.355 .20 & $1.105,97$ \\
Triliun \\
\hline 2016 & Triliun & $1.151,13$ \\
& $1.283,57$ & Triliun \\
\hline 2017 & Triliun & $1.315,00$ \\
& $1.424,00$ & Triliun \\
\hline 2018 & Triliun & Pajar \\
& &
\end{tabular}

Sumber : Direktoral Jendral Pajak 31 Desember 2018

Tidak tercapainya target penerimaan pajak ini salah satunya di sebabkan oleh adanya kecurangan pajak. Kecurangan pajak merupakan hal yang sangat serius di Indonesia dan sering dijumpai dalam administrasi perpajakan salah satunya yaitu penggelapan pajak (Fatimah dan Wardani, 2017). Penggelapan pajak mengacu pada tindakan membayar pajak lebih sedikit daripada yang harus dibayar secara

hukum

struktur pajak yang ditetapkan oleh negara (Bishop, 2001) itu dapat ditemukan di setiap Negara dan disetiap titik sejarah manusia, yang dilakukan baik oleh individu maupun oleh perusahaan. (Lanka, 2018).

Penggelapan pajak (tax evasion) mengandung arti sebagai usaha yang dilakukan oleh wajib pajak apakah berhasil atau tidak untuk mengurangi atau sama sekali menghapus hutang pajak yang berdasarkan ketentuan yang berlaku sebagai pelanggaran terhadap perundang-undangan perpajakan (Rahayu,2010 dalam Yulia dan Hertia, 2017). Tax avasion adalah perbuatan melanggar UUP dengan penyampaian di dalam surat pemberitahuan (SPT) tahunan jumlah penghasilan lebih rendah dari yang sebenarnya disatu pihak dan melaporkan jumlah penghasilan yang lebih tinggi dari sebenarnya di pihak lain (Abidin, 2016).

Wajib pajak yang melaporkan pajak terutangnya tidak sesuai dengan jumlah pajak yang di tetapkan, wajib pajak salah dalam menghitung, menyetor, melaporkan pajak terutangnya, serta adanya kemungkinan wajib pajak menyembunyikan sebagian penghasilannya sehingga jumlah pajak yang di bayarkan sedikit (Lebukan, 2011 dalam Abidin, 2016). Wajib pajak melakukan penggelapan pajak diduga ketika mereka percaya bahwa uang publik tidak dialokasikan secara efisien dari pemerintah kepada warga (Drogalas, Anagnostopoulou, Pazarskis, \& Petkopoulos, 2018). Serta mereka tidak percaya bahwa pemerintah berhak atas sebagian dari pendapatan mereka (McGee, 2014) dalam (McGee \& Shopovski, 2018). Ada berbagai macam kasus tindak penggelapan pajak di Indonesia contohnya kasus Albertus Irwan Tjahjadi Oedi yang melakukan tindak pidana pajak sebesar 10,68 miliar dan terbukti melakukan tindak pidana dengan sengaja SPT tahunan PPH WP badan dan SPT masa PPN tahun 2001 yang isinya tidak benar, serta memungut PPn tetapi tidak menyetorkan ke kas negara (Tempo.co). selain itu ada kasus penggelapan pajak yang di lakukan oleh tiga pengusaha di medan yang merugikan Negara hingga 7,9 miliar (mediaindonesia.com). Kasus selanjutnya yaitu mantan Bendahara Badan Layanan Umum Daerah (BLUD) Rumah Sakit lbu dan Anak (RSIA) Banda Aceh melakukan perbuatan pidana di bidang perpajakan. Tindak pidana yang di lakukannya yaitu telah memungut PPh Pasal 21, PPh Pasal 22, dan PPN dari Surat Perintah Pencariran Dana (SP2D) yang telah dicairkan, tetapi tidak menyetorkan pungutan pajak tersebut ke kas negara dan tidak melaporkan Surat Pemberitahuan (SPT) masa yang menjadi kewajibannya sebagai bendahara kepada 
Kantor Pelayanan Pajak (KPP) Pratama Banda Aceh (suara.com).

Masalah pengelakan/penggelapan pajak sangat serius di Indonesia diduga 110 triliun setiap tahunnya. Kebanyakan adalah badan usaha, sekitar 80 persen, sisanya adalah wajib pajak perorangan. (suara.com). Wajib pajak badan yang terdaftar di kantor pelayanan pajak pratama Subang tahun 2018 adalah 10.558 dan jumlah wajib pajak badan yang terdaftar untuk melaporkan SPT berjumlah 3.543 tetapi pada realisasinya hanya 1.494 wajib pajak yang melaporkan SPT.

Ada beberapa faktor yang mempengaruhi terjadinya penggelapan pajak, faktor yang pertama yaitu keadilan pajak. Keadilan pajak adalah sifat (perbuatan atau perlakuan) yang tidak sewenang-wenang atau tidak berat sebelah atas sistem perpajakan yang berlaku. Keadilan pengenaan dan pemungutan ini penting bagi kesadaran atau kepatuhan wajib pajak dalam memenuhi kewajiban perpajakannya, apabila apa yang mereka bayarkan sesuai dengan apa yang mereka dapatkan maka wajib pajak akan cenderung patuh dalam melakukan kewajiban perpajakannya sebaliknya apabila mereka mendapatkan perlakuan yang tidak adil maka mereka akan cenderung melakukan kecurangan pajak yaitu melakukan penggelapan pajak seperti yang di katakan dalam penelitian sebelumnya menurut Permatasari (2013) dalam Felicia (2017) semakin tidak adil sistem perpajakan yang berlaku menurut persepsi wajib pajak maka kepatuhan akan menurun dan cenderung memicu tindakan penggelapan pajak.

Faktor yang kedua yaitu sistem perpajakan. Menurut Irma (2014) Sistem perpajakan merupakan suatu sistem pemungutan pajak yang merupakan perwujudan dari pengabdian dan peran serta wajib pajak untuk secara langsung dan bersama-sama melaksanakan kewajiban perpajakan yang diperlukan untuk pembiayaan penyelenggaraan Negara dan pembangunan nasional. Sistem pemungutan pajak yang berlaku di Indonesia yaitu self assessment system dimana pemerintah memberikan kepercayaan secara penuh kapada wajib pajak untuk melakukan pemenuhan kewajiban perpajakannya atas dasar kesadaran dan rasa tanggungjawab, menurut Suminarsasi (2011) dalam Felicia (2017) Sistem ini akan berjalan dengan baik apabila masyarakat memiliki tingkat kesadaran perpajakan secara sukarela (voluntary tax compliance) yang tinggi. Tetapi sebaliknya apabila masyarakat memiliki tingkat kesadaran yang rendah maka self assessment sistem ini akan menimbulkan permasalahan serta kecurangan perpajakan dengan cara wajib pajak tidak melaporkan penghasilan dan sebenarnya atau bahkan ada wajib pajak yang tidak memenuhi kewajiban perpajakanya. Hal inilah yang menjadi salah satu faktor terhambat pencapaian target penerimaan pajak di Indonesia.

Faktor yang ketiga yaitu pemahaman perpajakan. Menurut Siti Resmi (2003), pengetahuan dan pemahaman akan peraturan perpajakan adalah proses dimana wajib pajak memahami tentang perpajakan dan menerapkan pengetahuan itu untuk membayar pajak. Apabila wajib pajak paham atas peraturan perpajakan maka wajib pajak akan taat dan patuh terhadap kewajibannya sebaliknya jika wajib pajak tidak paham atas peraturan perpajakan maka tidak menutup kemungkinan bila wajib pajak akan melakukan pelanggaran peraturan perpajakan contohnya dengan tidak melakukan kewajiban perpajakannya atau melakukan penggelapan pajak.

Selanjutnya faktor yang keempat yaitu tarif perpajakan. Menurut Wahyuningsi (2015) Tarif pajak merupakan jumlah persentase yang harus dibayarkan oleh wajib pajak dalam hal pemenuhan kewajiban perpajakannya sebagai warga negara. Apabila tarif perpajakan yang di berlakukan sesuai dengan pendapatan dan kemampuan wajib pajak maka mereka cenderung akan mematuhi kewajiban perpajakannya tetapi apabila tarif yang diberlakukannya terlalu tinggi dan tidak sesuai dengan kemampuan wajib pajak maka mereka akan merasa keberatan dalam menjalankan kewajibanya dan cenderung akan melakukan kecurangan dan 
melaporkan penghasilannya yang lebih rendah dari yang sebenarnya.

Faktor yang kelima adalah sanksi perpajakan. Sanksi perpajakan merupakan jaminan bahwa ketentuan peraturan perundang undangan perpajakan (norma perpajakan) akan dituruti/ditaati/dipatuhi. Atau bisa dengan kata lain sanksi perpajakan merupakan alat pencegah (preventif) agar wajib pajak tidak melanggar norma perpajakan (Kartika,2016 dalam Felicia,2017). Sanksi perpajakan juga merupakan hal penting karena apabila sanksi perpajakan bersifat tegas dan mengikat serta sanksi yang di berikan memberi efek jera dan berdampak langsung maka wajib pajak akan taat dan mematuhi peraturan perpajakan serta kewajiban perpajakannya. Namun apabila sanksinya tidak tegas dan mengikat serta tidak berdampak langsung maka tidak menutup kemungkinan untuk wajib pajak melakukan pelanggaran norma perpajakan.

Sejauh ini sudah banyak penelitian mengenai fenomena penggelapan pajak dalam berbagai sudut pandang namun dalam penelitian ini objek yang di telitinya yaitu wajib pajak badan. Penelitian ini bertujuan untuk mengetahui pengaruh keadilan pajak, sistem pajak, pemahaman pajak, tarif pajak dan sanksi pajak terhadap penggelapan pajak.

Pada penelitian sebelumnya yang sudah dilakukan oleh Yulia dan Hertia (2017) dan Felicia (2017) terdapat ketidakkonsistenan pada faktor yang mempengaruhi penggelapan pajak. Pada penelitian Yulia dan Hertia mengatakan bahwa sanksi pajak tidak berpengaruh terhadap Persepsi Pajak mengenai etika Penggelapan Pajak. Sedangkan pada penelitian Felicia (2017) menyebutkan bahwa sanksi pajak berpengaruh terhadap Persepsi Pajak mengenai etika Penggelapan Pajak.

Perbedaan dengan penelitian sebelumnya, penulis mengembangkan dari penelitian sebelumnya dan menambahkan variabel tarif pajak pada penelitian Yulia dan Hertia (2017) serta peneliti berfokus pada keadilan pajak, tarif pajak serta sanksi pajak terhadap persepsi pajak mengenai perilaku penggelapan pajak, karena penulis ingin mengetahui apakah keadilan pajak berpengaruh atau tidak terdadap penggelapan pajak kerena pada penelitian Hertia dan Yulia (2017) mengatakan berpengaruh sedangkan pada penelitian Marlina (2018) mengatakan tidak berpengaruh serta penulis ingin tahu seberapa besar pengaruh tarif pajak terhadap penggelapan pajak dan ingin tahu apakah sanksi pajak berpengaruh atau tidak terhadap penggelapan pajak karena pada penelitian Yulia dan Hertia (2017) mengatakan tidak berpengaruh sedangkan pada penelitian Felicia (2017) mengatakan sanksi pajak berpengaruh terhadap penggelapan pajak.

Penelitian ini bertujuan untuk mengetahui pengaruh keadilan, sistem, pemahaman, tarif dan sanksi perpajakan terhadap penggelapan pajak.

\section{KERANGKA TEORITIS DAN PENGEMBANGAN HIPOTESIS}

\section{Kerangka Teoritis}

Pajak merupakan kontribusi wajib kepada negara yang terutang oleh orang pribadi atau badan yang bersifat memaksa berdasarkan undang-undang perpajakan. Penerimaan pajak sejak lima tahun terakhir ini mengalami peningkatan, akan tetapi penerimaan pajak belum mencapai target yang di tentukan. Hal ini salah satunya di sebabkan oleh adanya penggelapan pajak yang di lakukan oleh wajib pajak badan.Teori yang digunakan dalam penelitian ini adalah Theory of Planned Behaviour menurut yezzie (2017) Teori ini merupakan hasil formulasi dari perluasan teori induk di bidang kajian keyakinan, sikap dan perilaku yang dikemukakan oleh Ajzen dan Fishbein pada tahun 1975 yang disebut Theory of Reasoned Action yang bertujuan untuk memperlihatkan hubungan dari perilakuperilaku yang dimunculkan oleh individu untuk menanggapi sesuatu. Theory of Planned Behavior, menjelaskan bahwa perilaku seseorang dipengaruhi oleh sikap (attitude), yang meliputi kepercayaankepercayaan normatif atau keadaan disekitar individu (subjektif norm). 
Hal ini menunjukan bahwa keadilan pajak, sistem pajak, pemahaman pajak, tarif pajak dan sanksi pajak dapat mempengaruhi wajib pajak dalam melakukan penggelapan pajak. Kemudian Perceived Behavioral Control yang mendorong atau memperlambat niat seseorang untuk berperilaku, Niat wajib pajak yang mengarah pada penggelapan pajak (Ameyaw \& Dzaka, 2016). Penggelapan pajak (Tax Evasion) adalah upaya yang disengaja oleh individu, badan-badan perusahaan, kepercayaan dan lembaga lain untuk secara tidak sah menolak untuk membayar pajak mereka dan melaporkan nilai keuntungan yang miring oleh dan sebagai sarana untuk menghindari (Lau, 2007) dalam (Bekoe et al., 2018).Berdasarkan teori dan latar belakang yang mendasari penggelapan pajak, terdapat beberapa faktor yang mempengaruhinya. Pertama, keadilan perpajakan yaitu Semakin tinggi tingkat keadilan pajak maka perilaku penggelapan pajak (tax evasion) dipandang sebagai perilaku yang tidak etis. Sebaliknya,semakin rendah tingkat keadilan pajak maka perilaku penggelapan pajak dianggap sebagai perilaku yang cenderung etis (yezzie, 2017). Yang kedua, sistem perpajakan yaitu apabila semakin baik sistem perpajakannya maka perilaku penggelapan pajak dipandang sebagai perilaku yang tidak etis.Sebaliknya semakin tidak baik suatu sistem perpajakan maka perilaku penggelapan pajak dianggap sebagai perilaku yang cenderung etis. Ketiga, pemahaman perpajakan yaitu apabila wajib pajak paham atas peraturan perundang-undangan maka wajib pajak tersebut akan taat terhadap peraturan dan tidak melakukan penggelapan pajak. Keempat, tarif pajak yaitu persentase untuk menghitung pajak terhutang. Tarif pajak yang tinggi akan meningkatkan beban pajak sehingga menurunkan pendapatan dari wajib pajak (Alligham dan Sandmo, 1972) dalam (Kurniawati \& Toly, 2014). Kelima, sanksi perpajakan alat pencegahan (preventif) agar Wajib Pajak tidak melanggar norma perpajakan. Dengan diterapkannya sanksi pajak maka wajib pajak akan merasa takut dan terbebani apabila mereka melalaikan atau melakukan penggelapan pajak. Adapun model kerangka pemikiran sebagai berikut.

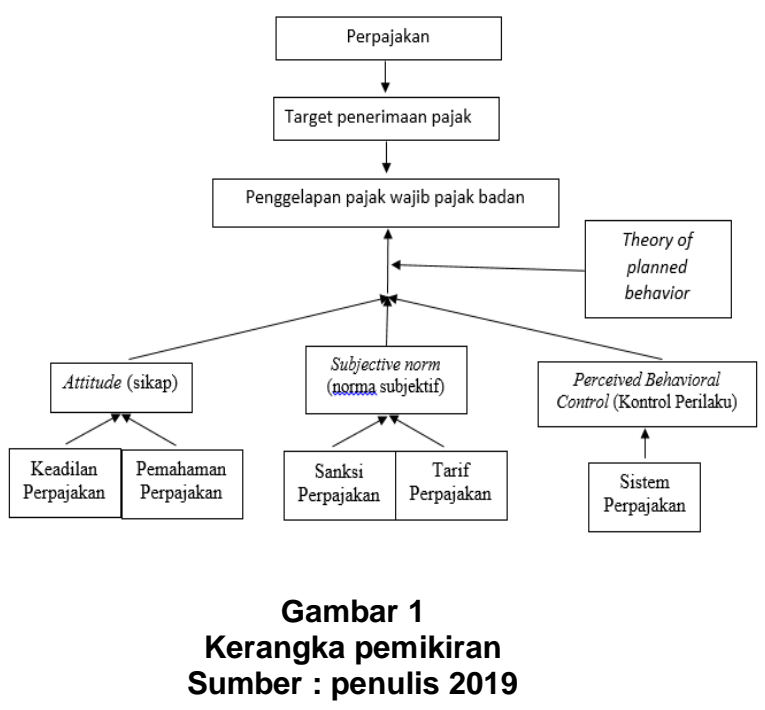

\section{Pengembangan Hipotesis}

\section{Pengaruh Keadilan Pajak terhadap Penggelapan Pajak \\ Menurut Mardiasmo (2011) dalam} Marlina (2018), untuk mencapai keadilan, undang-undang dan pelaksanaan pemungutan pajak harus adil. Adil dalam perundang-undangan diantaranya mengenakan pajak secara umum dan merata, serta disesuaikan dengan kemampuan masing-masing. Sedangkan adil dalam pelaksanaannya yakni dengan memberikan hak kepada wajib pajak untuk mengajukan keberatan, penundaan dalam pembayaran dan mengajukan banding kepada Majelis Pertimbangan Pajak.

Yezzie (2017) mengatakan Semakin tinggi tingkat keadilan pajak maka perilaku penggelapan pajak (tax evasion) dipandang sebagai perilaku yang tidak etis. Sebaliknya,semakin rendah tingkat keadilan pajak maka perilaku penggelapan pajak dianggap sebagai perilaku yang cenderung etis. Dalam penelitian yulia dan hertia (2017) menyebutka bahwa Terdapat pengaruh Keadilan Perpajakan terhadap Persepsi Pajak Mengenai Perilaku Penggelapan Pajak/ Tax Evasion.

Hal ini sejalan dengan penelitian yang di lakukan oleh (Yulia \& Hertia, 2017) 
bahwa keadilan pajak berpengaruh terhadap persepsi penggelapan pajak. Hasil penelitian (In \& Java, 2018) membuktikan bahwa semakin banyak penerapan keadilan dan sistem pajak di suatu negara, maka akan meningkatkan kepercayaan masyarakat terhadap pemerintah, sehingga penggelapan pajak yang melanggar aturan dan merugikan masyarakat tidak etis untuk dilakukan dan relevam dengan penelitian Yuliyanti dkk (2017) yang mengatakan bahwa keadilan pajak berpengaruh negatif terhadap persepsi penggelapan pajak badan. Maka dari uraian diatas dapat disimpulkan bahwa hipotesis pertama dalam penelitian ini adalah :

$\mathrm{H}_{1} \quad$ : Keadilan berpengaruh negatif terhadap persepsi Wajib Pajak mengenai perilaku penggelapan pajak.

\section{Pengaruh Sistem Pajak terhadap Penggelapan Pajak}

Sistem perpajakan di Indonesia menerapkan Self Assesment System yaitu suatu sistem pemungutan yang wajib pajaknya boleh menghitung, membayar, dan melaporkan sendiri besarnya pajak yang harus disetor. Dalam sistem ini, wajib pajak bersifat aktif, sedangkan fiskus (pemerintah) hanya mengawasi. Setiap wajib pajak merupakan pihak yang akan menyetorkan uang mereka maka dari itu pihak pemerintah selaku pemungut pajak, harus membuat sebuah sistem perpajakan yang cenderung praktis namun efektif dan efisien. Sistem perpajakan memiliki kontribusi terhadap penerimaan pajak, dimana jika sistem perpajakan yang diterapkan baik maka wajib pajak akan melaksanakan kewajibannya untuk membayar pajak (Rahman, 2013) dalam (Marlina,2018).

Menurut Yezzie (2017) Apabila Wajib Pajak merasa sistem perpajakan yang berlaku sudah baik maka Wajib Pajak akan memberikan respon yang baik dan taat dalam melaksanakan kewajiban perpajakannya. Namun, jika Wajib Pajak merasa bahwa sistem perpajakan yang berlaku belum cukup mengakomodasi segala keperluannya, maka wajib pajak akan cenderung tidak taat atau menghindar dari kewajiban perpajakannya. Dengan pengertian lain, semakin baik sistem perpajakannya maka perilaku penggelapan pajak dipandang sebagai perilaku yang tidak etis. Sebaliknya semakin tidak baik suatu sistem perpajakan maka perilaku penggelapan pajak dianggap sebagai perilaku yang cenderung etis.

Pada hasil penelitiannya terbukti bahwa sistem perpajakan berpengaruh terhadap Persepsi wajib pajak etika penggelapan pajak / Tax Evasion. Hal ini didukung oleh penelitian (Pulungan, 2015) dan Putri (2017) bahwa sistem pajak berpengaruh terhadap penggelapan pajak. Berdasarkan penjelasan diatas maka hipotesis yang kedua adalah :

$\mathrm{H}_{2} \quad$ : Sistem pajak berpengaruh negatif terhadap persepsi wajib pajak mengenai perilaku penggelapan pajak.

\section{Pengaruh Pemahaman Pajak terhadap Penggelapan Pajak}

Pemahaman akan peraturan perpajakan erat kaitannya dengan pembayaran pajak. Rachmadi \& Zulaikha (2014) dalam Marlina (2018) mengatakan bahwa pengetahuan dan pemahaman akan peraturan perpajakan adalah proses dimana wajib pajak memahami tentang perpajakan dan menerapkan pengetahuan itu untuk membayar pajak. Setiap wajib pajak yang mampu memahami perpajakan secara mutlak, maka akan memahami pula bahwa penggelapan pajak itu tidak boleh dilakukan.

Menurut Sholichah (2005) dalam Yezzie (2017), wajib pajak yang tidak memahami peraturan perpajakan secara jelas cenderung akan menjadi Wajib Pajak yang tidak taat. Wajib Pajak akan beranggapan tindakan penggelapan pajak adalah tidak etis jika memiliki pemahaman perpajakan yang baik. Hal ini terbukti dari penelitianya yang menyebutkan bahwa pemahaman pajak berpengaruh terhadap penggelapan pajak. Hal ini didukung oleh penelitian sebelumnya bahwa pemahaman wajib pajak berpengaruh signifikan dan positif terhadap persepsi wajib pajak mengenai penggelapan pajak (Marlina, 2018). 
Pemahaman perpajakan yang dimiliki wajib pajak secara parsial berpengaruh signifikan terhadap persepsi wajib pajak atas perilaku penggelapan pajak. Hasil pengujian variabel pemahaman perpajakan menunjukkan adanya indikasi nilai yang negatif. Hal ini mengindikasikan bahwa semakin wajib pajak memahami aturan, tata cara, tentang ketentuan perpajakan ketika melakukan kewajiban perpajakan maka perilaku penggelapan pajak dipandang tidak etis untuk dilakukan (Rachmadi \& Zulaikha, 2014). Maka berdasarkan uraian diatas dapat disimpulkan bahwa hipotesis ketiga adalah :

$\mathrm{H}_{3} \quad$ : Pemahaman pajak berpengaruh negatif terdahap persepsi wajib pajak terdahap perilaku penggelapan pajak.

\section{Pengaruh Tarif Pajak terhadap Penggelapan Pajak}

Pungutan pajak yang dilakukan di Indonesia menggunakan tarif pajak. Penentuan mengenai pajak yang terutang sangat ditentukan oleh tarif pajak. Tarif merupakan persentase untuk menghitung pajak terhutang. Dalam penetapan tarif pajak harus berdasarkan azas keadilan. Salah satu syarat pemungutan pajak adalah keadilan, baik keadilan dalam prinsip maupun dalam pelaksanaannya. Pemerintah dapat menciptakan keseimbangan (Yuliyanti, Titisari, \& Nurlela, 2017).

Dalam penghitungan pajak yang terutang digunakan tarif pajak yang kemudian dikalikan dengan dasar pengenaan pajak. Beberapa studi menunjukkan bahwa tarif pajak yang tinggi memicu penggelapan pajak. Tarif pajak yang tinggi akan meningkatkan beban pajak sehingga menurunkan pendapatan dari wajib pajak (Alligham dan Sandmo, 1972) dalam (Kurniawati \& Toly, 2014).

Jika tarif pajak terlalu tinggi maka penggelapan pajak juga akan tinggi. Penerapan tarif pajak yang terlalu tinggi akan berbanding lurus dengan tingkat penggelapan pajak. Semakin tinggi tarif pajak, maka akan berdampak pada peningkatan tax evasion di masyarakat. Penelitian (Fisman dan Wei,2004) dalam
(Kiri, 2016) menyimpulkan bahwa untuk kenaikan tarif pajak satu persen, penggelapan pajak meningkat dengan tiga persen. Hal tersebut terbukti dalam hasil penelitiannya bahwa tarif pajak berpengaruh positif dan signifikan terhadap persepsi wajib pajak mengenai penggelapan pajak (Kurniawati \& Toly, 2014)

Hal ini sejalan dengan penelitian Felicia (2017) bahwa tarif pajak berpengaruh terhadap persepsi wajib pajak mengenai etika penggelapan pajak. Pada Penelitian (Mason dan Calvin,1978) dalam (Kiri, 2016) menyimpulkan bahwa ada hubungan positif antara tarif pajak dan penggelapan pajak. Maka berdasarkan penjelasan diatas maka hipotesis yang keempat adalah :

$\mathrm{H}_{4} \quad$ : Tarif pajak berpengaruh positif terdahap persepsi wajib pajak terdahap perilaku penggelapan pajak.

\section{Pengaruh Sanksi Pajak terhadap Penggelapan Pajak}

Mardiasmo (2009) dalam Yezzie (2017) menyatakan Sanksi Perpajakan merupakan jaminan bahwa ketentuan peraturan perundang-undangan perpajakan (norma perpajakan) akan ditaati. Sanksi perpajakan merupakan alat pencegahan (preventif) agar Wajib Pajak tidak melanggar norma perpajakan. Penerapan sanksi diterapkan sebagai akibat tidak terpenuhinya kewajiban perpajakan oleh Wajib Pajak sebagaimana diamanatkan oleh Undang-Undang perpajakan.

Dengan diterapkan nya sanksi pajak maka wajib pajak akan merasa takut dan terbebani apabila mereka melalaikan atau melakukan penggelapan pajak. Semakin besarnya denda yang dibebankan akan mendorong wajib pajak untuk berperilaku tidak patuh, dan semakin banyak celah kesempatan yang dimiliki wajib pajak untuk melakukan penggelapan pajak. Pareek (2001) dalam (Rachmadi \& Zulaikha, 2014).

$\mathrm{Hal}$ ini terlihat dari hasil penelitian Yuliyanti dkk (2017) mengatakan bahwa sanksi pajak berpengaruh negatif terhadap persepsi penggelapan pajak badan. Dan di 
perkuat oleh penelitian (Felicia, 2017) yang mengatakan bahwa sanksi pajak berpengaruh terhadap persepsi wajib pajak mengenai etika penggelapan pajak. Dari penjelasan tersebut maka dapat simpulkan hipotesis yang kelima adalah :

$\mathrm{H}_{5}$ : Sanksi pajak berpengaruh negatif terdahap persepsi wajib pajak terdahap perilaku penggelapan pajak.

\section{Pengaruh Keadilan, Sistem,} Pemahaman, Tarif dan Sanksi Perpajakan terhadap Penggelapan Pajak

Setelah variabel diuji secara parsial atau masing-masing pengaruhnya terhadap penggelapan pajak, dalam penelitian ini diuji kembali secara simultan atau secara bersama-sama pengaruh dari keadilan perpajakan, sistem perpajakan, pemahaman perpajakan, tarif perpajakan dan sanksi perpajakan terhadap penggelapan pajak. Maka dari itu hipotesis yang diajukan dalam penelitian ini yaitu:

$\mathrm{H}_{6}$ : Keadilan, sistem, pemahaman, tarif dan sanksi perpajakan berpengaruh terhadap penggelapan pajak.

\section{METODOLOGI PENELITIAN}

\section{Metode Penelitian}

Metode yang digunakan dalam penelitian ini adalah metode penelitian kuantitatif. Metode penelitian kuantitatif diartikan sebagai metode penelitian yang berlandaskan pada filsafat positiviste, digunakan untuk meneliti pada populasi atau sampel tertentu, pengumpulan data menggunakan instrument penelitian, analisis data bersifat kuantitatif/statistic, dengan tujuan untuk menguji hipotesis yang tetah di terapkan (Sugiyono,2016).

\section{Sumber dan Teknik Pengumpulan Data}

Sumber data yang digunakan dalam penelitian ini adalah data primer. menurut Umma Dan Bougie (2017) data primer yaitu data yang mengacu pada informasi yang diperoleh secara langsung (dari tangan pertama) oleh peneliti. Data primer tersebut di dapat dari penyebaran kuesioner kepada pihak-pihak yang terkait dengan penelitian ini.

Teknik pengumpulan data yang digunakan dalam penelitian ini adalah kuesioner. Menurut Umma dan Bougie (2017) kuesioner adalah daftar pertanyaan tertulis yang telah dirumuskan sebelumnya dimana responden akan mencatat jawaban mereka, biasanya dalam alternative yang didefinisikan dengan jelas.

\section{Populasi dan Sampel}

Menurut Sugiyono (2015) Populasi adalah wilayah generalisasi yang terdiri atas obyek/subjek yang memiliki kualitas dan karakteristik tertentu yng ditetapkan oleh peneliti untuk dipelajari dan kemudian ditarik kesimpulannya. Sedangkan Sampel adalah sebagian dari jumlah dan karakteristik yang dimiliki oleh populasi tersebut (Sugiyono,2015). Populasi yang digunakan dalam objek penelitian ini adalah wajib pajak badan yang terdaftar di kantor pelayanan pajak pratama yang terletak di kabupaten Subang yaitu KPP Pratama Subang. Jumlah sampel dari penelitian ini yaitu 100 wajib pajak badan yang terdaftar di kantor pelayanan pajak pratama subang. Jumlah sampel dalam penelitian ini di tentukan sesuai dengan pendapat Sekaran (2006) bahwa ukuran sampel yang dapat digunakan adalah 30500 sampel.

\section{Teknik Pemilihan Sampel}

Menurut Sugiono (2015) teknik sampling merupakan teknik pengambilan sampel. Teknik sampling pada dasarnya dikelompokan menjadi dua yaitu :

1. Probability Sampling, adalah teknik pengambilang sampel yang memberikan peluang yang sama bagi setiap unsur (anggota) populasi untuk dipilih menjadi sampel.

2. Nonprobality Sampilng, adalah teknik pengambilan sampel yang tidak memberi peluang/kesempatan sama bagi setiap unsur (anggota) populasi untuk dipilih menjadi sampel.

Teknik pemilihan sampel dalam penelitian ini adalah sampling incidental. Menurut Sugiyono (2015) Sampling insidental adalah teknik penentuan sampel 
berdasarkan kebetulan atau siapa saja yang secara kebetulan/insidental bertemu dengan peneliti dapat digunakan sebagai sampel, bila yang kebetulan di temui itu cocok sebagai sumber data.

\section{Definisi Dan Pengukuran Variabel Penelitian}

Labovitz dan Hagedorn (1981) dalam Yezzie (2017) mengemukakan definisi operasional sebagai suatuperincian dari prosedur-prosedur yang dapat diobservasi, yang digunakan untuk mengidentifikasi apa yang dimaksud (referen) oleh kata yang didefinisikan. Suatu variabel didefinisikan secara operasional bila langkah-angkah dalam observasi atau pengukurannya jelas dinyatakan. Variabel yang digunakan dalam penelitian ini adalah variabel bebas dan variabel terikat :

a. Variabel bebas (independent variable) adalah variabel yang mempengaruhi dan menyebabkan timbulnya atau berubahnya variabel terikat.

b. Variabel terikat (dependent variable) adalah variabel yang dipengaruhi oleh variabel bebas.

Definisi operasional memuat indikator dari suatu variabel yang memungkinkanpeneliti mengumpulkan data secara relevan sehingga dari masingmasing variabel tersebut lebih terarah dan sesuai dengan metode pengukuran yang telah direncanakan.

\section{Teknik Pengolahan Data}

Penelitian akan menggunakan regresi linier berganda dengan menggunakan program pengolah data SPSS versi 22. Regresi linier berganda adalah model regresi linear dengan melibatkan lebih dari satu variable bebas atau predictor. Dalam bahasa inggris, istilah ini disebut dengan multiple linear regression.

\section{Uji Kualitas Data (Instrumen Penelitian) Uji Validitas}

Uji validitas adalah suatu alat yang menunjukkan seberapa jauh suatu instrumen memiliki ketepatan dan kecermatan dalam melakukan fungsi ukurnya. Arikunto (2006: 168-169) dalam
Yezzie (2017) mengatakan, tinggi rendahnya validasi instrumen menunjukkan sejauh mana data yang terkumpul tidak menyimpang dari gambaran tentang variabel yang dimaksud. Uji signifikansi dilakukan denganmembandingkan nilai $r$ hitung dengan $r$ tabel untuk degree of freedo $m$ (df) $=n-2$, dalam hal ini $n$ adalah jumlah sampel. Jika $r$ hitung lebih besar dari $r$ tabel dan nilai positif maka butir atau pernyataan atau indikator tersebut dinyatakan valid (Ghozali, 2016).

\section{Uji Reliabilitas}

Selain uji validitas yang melihat tingkat ketepatan suatu instrumen, instrumen juga harus memenuhi standar reliabilitas. Arikunto (2006: 178) dalam Yezzie (2017) menyatakan bahwa reliabilitas menunjukkan pada suatu pengertian bahwa suatu instrumen cukup dapat dipercaya untuk digunakan sebagai alat pengumpul data karena instrument tersebut sudah cukup baik.

Realibilitas digunakan untuk menunjukkan sejauh mana alat ukur dapat dipercaya atau diandalkan. Dalam penelitiaan ini uji reabilitas menggunakan rumus

Koefisien Alfa (Croncbach), dengan menggunakan alat bantu SPSS 22. Suatu konstruk dikatakan reliabel jika memberikan nilai

Cronbach Alpha > 0,60 (Nunnaly, 1960 dalam Umiyati dan Nurmalasari,2016).

\section{Teknik Analisis Data}

Penganalisisan data yang akan dilakukan dalam penelitian ini adalah Analisis Deskriptif. Analisis deskriptif adalah statistik yang digunakan untuk menganalisis data dengan cara mendeskripsikan atau menggambarkan data yang telah terkumpul sebagaimana adanya tanpa bermaksud membuat kesimpulan yang berlaku untuk umum atau generalisasi (Sugiyono,2015).

\section{Uji Asumsi Klasik}

Langkah awal sebelum melakukan uji statistik yaitu dilakukan adalah memastikan setiap variabel berdistribusi normal dan independen.

\section{Uji Normalitas}


Uji Normalitas berguna untuk menentukan data yang telah dikumpulkan berdistribusi normal atau diambil dari populasi normal. Metode klasik dalam pengujian normalitas suatu data tidak begitu rumit. Berdasarkan pengalaman empiris beberapa pakar statistik, data yang banyaknya lebih dari 30 angka $(n>$ 30), maka sudah dapat diasumsikan berdistribusi normal. Biasa dikatakan sebagai sampel besar.

Namun untuk memberikan kepastian, data yang dimiliki berdistribusi normal atau tidak, sebaiknya digunakan uji normalitas. Karena belum tentu data yang lebih dari 30 bisa dipastikan berdistribusi normal, demikian sebaliknya data yang banyaknya kurang dari 30 belum tentu tidak berdistribusi normal, untuk itu perlu suatu pembuktian.

\section{Uji Multikolinieritas}

Uji multikolinearitas digunakan untuk mengetahui ada tidaknya gejala multikolinearitas. Artinya variabel independen yang atu dengan yang lain dalam model regresi berganda tidak saling berhubungan secara sempurna. Untuk mengujinya dapat dilihat dari besarnya nilai Tolerance dan VIF (Variance Inflation Factor) mealui program SPSS. Tolerance mengukur variabilitas variabel terpilih yang tidak dijelaskan oleh variabel independen lainnya. Jika VIF kurang dari 10 dan nilai toleransi lebih dari 0,1 maka regresi bebas dari multikolinieritas.

\section{Uji Heteroskedastisitas}

Uji heteroskedastisitas bertujuan menguji apakah dalam model regresi terjadi ketidaksamaan varian dari residual satu pengamatan ke pengamatan lain. Jika variance dari residual satu pengamatan ke pengamatan lain tetap, maka disebut Homoskedastisitas dan jika berbeda disebut Heteroskedastisitas. Model regresi yang baik adalah yang Homoskedastisitas atau tidak terjadi Heteroskedastisitas (Ghozali, 2016). Dalam mendeteksi ada atau tidaknya heteroskedastisitas dapat menggunakan uji heteroskedastisitas dengan rank spearman, dimana profitabilitas signifikan dari variabel independen harus diatas tingkat kepercayaan 5\%, maka dapat dinyatakan tidak terjadi heteroskedastisitas.

\section{Uji Hipotesis Data \\ Analisis Regresi Berganda}

Kegunaan analisis regresi ganda linier adalah untuk menemukan model regresi yang paling sesuai menggambarkan faktor-faktor yang berhubungan dengan

variabel dependen. Berikut model persamaan regresi ganda merupakan perluasan regresi sederhana yang dikemukakan dalam buku Sugiyono (2013), yaitu :

$Y=a+b 1 \times 1+b 2 \times 2+b 3 \times 3+b 4 \times 4+b 5 \times 5$ Keterangan :

$$
\begin{array}{ll}
\mathrm{Y} & =\text { Penggelapan Pajak } \\
\mathrm{a} & =\text { Parameter ( intercept) } \\
\mathrm{b} & =\text { Koefisien Regresi } \\
\mathrm{x} 1 & =\text { Keadilan Perpajakan } \\
\mathrm{x} 2 & =\text { Sistem Perpajakan } \\
\mathrm{x} 3 & =\text { Pemahaman Perpajakan } \\
\mathrm{x} 4 & =\text { Tarif Perpajakan } \\
\mathrm{x} 5 & =\text { Sanksi perpajakan }
\end{array}
$$

\section{Uji R2 atau Uji Koefisien Determinasi}

Uji R2 (uji determinasi) digunakan untuk mengukur seberapa besar kontribusi variabel bebas $(\mathrm{X})$ terhadap variabel terikat $(Y)$. Ketika nilai $R 2$ semakin besar (mendekati satu) menunjukkan semakin baik kemampuan variabel $X$ menerangkan variabel $Y$ dimana $0<R 2<1$. Sebaliknya, ketika R2 semakin kecil (mendekati nol), maka akan dapat dikatakan bahwa pengaruh variabel bebas adalah kecil terhadap variabel terikat. Hal ini berarti model yang digunakan tidak kuat untuk menerangkan pengaruh variabel bebas yang diteliti terhadap variabel terikat.

\section{Uji F (f-test)}

Uji $F$ digunakan untuk menguji variabel bebas secara bersama-sama (simultan) mempunyai pengaruh yang signifikan atau tidak terhadap variabel terikat. Adapun ketentuan dalam pengujian ini yaitu sebagai berikut:

1) $H_{0}: \beta=0$, artinya variabel-variabel bebas (keadilan perpajakan, sistem perpajakan, pemahaman perpajakan, tarif perpajakan dan sanksi perpajakan) tidak mempunyai pengaruh yang signifikan secara simultan atau 
bersama-sama terhadap variabel terikatnya (penggelapan pajak).

2) $\mathrm{H}_{1}: \beta \neq 0$, artinya variabel-variabel bebas (keadilan perpajakan, sistem perpajakan, pemahaman perpajakan, tarif perpajakan dan sanksi perpajakan) mempunyai pengaruh yang signifikan secara bersama-sama terhadap variabel terikatnya (penggelapan pajak).

Adapun kriteria pengambilan keputusan dengan menggunakan angka probabilitas signifikansi dan $\mathrm{F}$ tabel:

1) Apabila probabilitas signifikansi $>$ 0.05, maka $\mathrm{H}_{0}$ diterima dan $\mathrm{H}_{1}$ ditolak artinya keadilan perpajakan, sistem perpajakan, pemahaman perpajakan, tarif perpajakan dan sanksi perpajakan secara simultan atau bersama-sama tidak berpengaruh terhadap variabel penggelapan pajak.

2) Apabila probabilitas signifikansi < 0,05, maka $\mathrm{H}_{0}$ ditolak dan $\mathrm{H}_{1}$ diterima artinya keadilan perpajakan, sistem perpajakan, pemahaman perpajakan, tarif perpajakan dan sanksi perpajakan secara simultan atau bersama-sama mempengaruhi variabel penggelapan pajak.

3) Membandingkan nilai $F$ hitung dengan $\mathrm{F}$ tabel

a) Apabila $\mathrm{F}$ tabel $>\mathrm{F}$ hitung, maka $\mathrm{H}_{0}$ diterima dan $\mathrm{H}_{1}$ ditolak.

b) Apabila $\mathrm{F}$ tabel < $\mathrm{F}$ hitung, maka $\mathrm{H}_{0}$ ditolak dan $\mathrm{H}_{1}$ diterima.

\section{Uji Parsial (uji t)}

Menurut Ghozali (2016), uji statistik t pada dasarnya menunjukan seberapa jauh pengaruh suatu variabel penjelas/independen secara individual dalam menerangkan variasi variabel dependen. Adapun ketentuan dalam pengujian ini yaitu sebagai berikut:

1) $\mathrm{H}_{0}: \beta=0$, artinya variabel-variabel bebas (keadilan perpajakan, sistem perpajakan, pemahaman perpajakan, tarif perpajakan dan sanksi perpajakan) tidak mempunyai pengaruh yang signifikan secara simultan atau bersama-sama terhadap variabel terikatnya (penggelapan pajak).

2) $\mathrm{H}_{1}: \beta \neq 0$, artinya variabel-variabel bebas (keadilan perpajakan, sistem perpajakan, pemahaman perpajakan, tarif perpajakan dan sanksi perpajakan) mempunyai pengaruh yang signifikan secara bersama-sama terhadap variabel terikatnya penggelapan pajak).

Adapun kriteria pengambilan keputusan dengan menggunakan angka probabilitas signifikansi dan t tabel:

1) Apabila probabilitas signifikansi > 0.05, maka $\mathrm{H}_{0}$ diterima dan $\mathrm{H}_{1}$ ditolak artinya keadilan perpajakan, sistem perpajakan, pemahaman perpajakan, tarif perpajakan dan sanksi perpajakan secara simultan atau bersama-sama tidak berpengaruh terhadap variabel penggelapan pajak.

2) Apabila probabilitas signifikansi < 0,05, maka $\mathrm{H}_{0}$ ditolak dan $\mathrm{H}_{1}$ diterima artinya keadilan perpajakan, sistem perpajakan, pemahaman perpajakan, tarif perpajakan dan sanksi perpajakan secara simultan atau bersama-sama mempengaruhi variabel penggelapan pajak.

3) Membandingkan nilai T hitung dengan T tabel

a) Apabila $T$ tabel $>T$ hitung, maka $\mathrm{H}_{0}$ diterima dan $\mathrm{H}_{1}$ ditolak.

b) Apabila $T$ tabel $<T$ hitung, maka $\mathrm{H}_{0}$ ditolak dan $\mathrm{H}_{1}$ diterima.

\section{HASIL DAN PEMBAHASAN}

\section{Hasil Uji Instrumen Penelitian Uji Validitas}

Hasil uji validitas untuk kuesioner yang berjumlah 110 ditentukan dengan df $=110-2=108$ pada tingkat signifikansi (a) sebesar $5 \%$ atau 0.05 diperolah nilai $r$ tabel $=0.1874$. Maka instrumen dinyatakan valid apabila memiliki nilai $r$ hitung lebih besar dari $r$ tabel. Berikut rincian dari masing-masing variabel :

a. Keadilan perpajakan (X1)

Uji validitas untuk variabel keadilan perpajakan $\left(\mathrm{X}_{1}\right)$ terdiri dari 4 butir pernyataan. Hasil pengujian menunjukan bahwa semua 
pernyataan telah valid, karena nilai $r$ hitung lebih besar dari $r$ tabel, maka itemitem tersebut dapat digunakan dalam model regresi. Berikut rincian hasil pengujian variabel $X_{1}$ :

Tabel 1

Hasil Validitas Keadilan Perpajakan

Item-Total Statistics

\begin{tabular}{|c|r|r|l|}
\hline & $\begin{array}{c}\text { Corrected } \\
\text { Item-Total } \\
\text { Correlation }\end{array}$ & $\mathrm{r}$ tabel & Hasil \\
\hline $\mathrm{X} 1.1$ & 0.594 & 0.1874 & Valid \\
\hline $\mathrm{X} 1.2$ & 0.450 & 0.1874 & Valid \\
\hline $\mathrm{X} 1.3$ & 0.674 & 0.1874 & Valid \\
\hline $\mathrm{X} 1.4$ & 0.549 & 0.1874 & Valid \\
\hline
\end{tabular}

Sumber : Hasil pengolahan data dengan SPSS versi 22

b. Sistem perpajakan (X2)

Uji validitas untuk variabel sistem perpajakan $\left(\mathrm{X}_{2}\right)$ terdiri dari 5 butir pernyataan. Hasil pengujian menunjukan bahwa semua pernyataan telah valid, karena nilai $r$ hitung lebih besar dari $r$ tabel, maka itemitem tersebut dapat digunakan dalam model regresi. Berikut rincian hasil pengujian variabel $\mathrm{X}_{2}$ :

Tabel 2

Hasil Validitas Sistem

Perpajakan

Item-Total Statistics

\begin{tabular}{|l|r|r|l|}
\hline & $\begin{array}{c}\text { Corrected } \\
\text { Item-Total } \\
\text { Correlation }\end{array}$ & $\mathrm{r}$ tabel & Hasil \\
\hline $\mathrm{X} 2.1$ & 0.713 & 0.1874 & Valid \\
\hline $\mathrm{X} 2.2$ & 0.689 & 0.1874 & Valid \\
\hline X2.3 & 0.634 & 0.1874 & Valid \\
\hline X2.4 & 0.597 & 0.1874 & Valid \\
\hline X2.5 & 0.712 & 0.1874 & Valid \\
\hline
\end{tabular}

Sumber : Hasil pengolahan data

dengan SPSS versi 22 model regresi. Berikut rincian hasil pengujian variabel $\mathrm{X}_{3}$ :

Tabel 3

Hasil Validitas Pemahaman

Perpajakan

Item-Total Statistics

\begin{tabular}{|c|r|r|c|}
\hline & $\begin{array}{c}\text { Corrected } \\
\text { Item-Total } \\
\text { Correlation }\end{array}$ & r tabel & Hasil \\
\hline X3.1 & 0.775 & 0.1874 & Valid \\
\hline X3.2 & 0.754 & 0.1874 & Valid \\
\hline X3.3 & 0.681 & 0.1874 & Valid \\
\hline X3.4 & 0.767 & 0.1874 & Valid \\
\hline X3.5 & 0.701 & 0.1874 & Valid \\
\hline X3.6 & 0.713 & 0.1874 & Valid \\
\hline X3.7 & 0.830 & 0.1874 & Valid \\
\hline X3.8 & 0.384 & 0.1874 & Valid \\
\hline X3.9 & 0.751 & 0.1874 & Valid \\
\hline S3mber
\end{tabular}

Sumber : Hasil pengolahan data dengan SPSS versi 22

d. Tarif perpajakan (X4)

Uji validitas untuk variabel tarif perpajakan $\left(\mathrm{X}_{4}\right)$ terdiri dari 5 butir pernyataan. Hasil pengujian menunjukan bahwa semua pernyataan telah valid, karena nilai $r$ hitung lebih besar dari $r$ tabel, maka itemitem tersebut dapat digunakan dalam model regresi. Berikut rincian hasil pengujian variabel $X_{4}$ :

Tabel 4

Hasil Uji Validitas Tarif Perpajakan Item-Total Statistics

\begin{tabular}{|l|r|r|l|}
\hline & $\begin{array}{c}\text { Corrected } \\
\text { Item-Total } \\
\text { Correlation }\end{array}$ & $r$ tabel & Hasil \\
\hline X4.1 & 0.370 & 0.1874 & Valid \\
\hline X4.2 & 0.327 & 0.1874 & Valid \\
\hline X4.3 & 0.427 & 0.1874 & Valid \\
\hline X4.4 & 0.432 & 0.1874 & Valid \\
\hline X4.5 & 0.501 & 0.1874 & Valid \\
\hline
\end{tabular}

Sumber: Hasil pengolahan data dengan SPSS versi 22

e. Sanksi perpajakan (X5)

Uji validitas untuk variabel sanksi perpajakan $\left(X_{5}\right)$ terdiri dari 4 butir pernyataan. Hasil pengujian menunjukan bahwa semua pernyataan telah valid, karena nilai $r$ hitung lebih besar dari $r$ tabel, maka itemitem tersebut dapat digunakan dalam 
model regresi. Berikut rincian hasil pengujian variabel $\mathrm{X}_{5}$ :

Tabel 5

Hasil Uji Validitas Sanksi

Perpajakan

Item-Total Statistics

\begin{tabular}{|c|r|r|c|}
\hline & $\begin{array}{c}\text { Corrected } \\
\text { Item-Total } \\
\text { Correlation }\end{array}$ & $\mathrm{r}$ tabel & Hasil \\
\hline X5.1 & 0.865 & 0.1874 & Valid \\
\hline X5.2 & 0.675 & 0.1874 & Valid \\
\hline X5.3 & 0.860 & 0.1874 & Valid \\
\hline X5.4 & 0.862 & 0.1874 & Valid \\
\hline
\end{tabular}

Sumber : Hasil pengolahan data dengan SPSS versi 22

f. Penggelapan Pajak (Y)

Uji validitas untuk variabel penggelapan pajak (Y) terdiri dari 9 butir pernyataan. Hasil pengujian menunjukan bahwa semua pernyataan telah valid, karena nilai $r$ hitung lebih besar dari $r$ tabel, maka itemitem tersebut dapat digunakan dalam model regresi. Berikut rincian hasil pengujian variabel $(\mathrm{Y})$ :

\section{Tabel 6}

Hasil Uji Validitas

Penggelapan Pajak

Item-Total Statistics

\begin{tabular}{|c|r|r|c|}
\hline & $\begin{array}{r}\text { Corrected } \\
\text { Item-Total } \\
\text { Correlation }\end{array}$ & r tabel & Hasil \\
\hline Y.1 & 0.648 & 0.1874 & Valid \\
\hline Y.2 & 0.670 & 0.1874 & Valid \\
\hline Y.3 & 0.635 & 0.1874 & Valid \\
\hline Y.4 & 0.647 & 0.1874 & Valid \\
\hline Y.5 & 0.529 & 0.1874 & Valid \\
\hline Y.6 & 0.600 & 0.1874 & Valid \\
\hline Y.7 & 0.712 & 0.1874 & Valid \\
\hline Y.8 & 0.541 & 0.1874 & Valid \\
\hline Y.9 & 0.274 & 0.1874 & Valid \\
\hline
\end{tabular}

Sumber : Hasil pengolahan data dengan SPSS versi 22

\section{Uji Reliabilitas}

Uji reliabilitas dilihat berdasarkan nilai Cronbach Alpha ( $\alpha$ ), dimana suatu variabel dikatakan reliabel apabila nilai Cronbach Alpha $(\alpha)>0.60$. Hasil pengujian menunjukan bahwa semua variabel telah dinyatakan reliabel, berikut adalah hasil uji reliabilitas dari masingmasing variabel :

Tabel 7

Hasil Uji Reliabilitas

\begin{tabular}{|c|c|c|c|}
\hline Variabel & $\begin{array}{c}\text { Cronbach's } \\
\text { Alpha Based } \\
\text { on } \\
\text { Standardized } \\
\text { Items }\end{array}$ & $\begin{array}{c}\text { Batas } \\
\text { Cronbach's } \\
\text { Alpha }\end{array}$ & Hasil \\
\hline $\begin{array}{c}\text { Keadilan } \\
\text { perpajakan }\end{array}$ & 0.763 & 0.60 & Reliabel \\
\hline $\begin{array}{c}\text { Sistem } \\
\text { perpajakan }\end{array}$ & 0.854 & 0.60 & Reliabel \\
\hline $\begin{array}{c}\text { Pemahaman } \\
\text { perpajakan }\end{array}$ & 0.915 & 0.60 & Reliabel \\
\hline $\begin{array}{c}\text { Tarif } \\
\text { perpajakan }\end{array}$ & 0.657 & 0.60 & Reliabel \\
\hline $\begin{array}{c}\text { Sanksi } \\
\text { perpajakan }\end{array}$ & 0.917 & 0.60 & Reliabel \\
\hline $\begin{array}{c}\text { Penggelapan } \\
\text { pajak }\end{array}$ & 0.862 & 0.60 & Reliabel \\
\hline
\end{tabular}

Sumber : Hasil pengolahan data dengan SPSS versi 22

\section{Analisis Regresi Linier}

Berikut ini adalah tabel hasil regresi berganda yang membuktikan pengaruh ada tidaknya pengaruh dari variabel Keadilan Perpajakan (X1), Sistem Perpajakan (X2), Pemahaman Perpajakan (X3), Tarif Perpajakan (X4), dan Sanksi Perpajakan (X5) terhadap Penggelapan Pajak (Y).

\section{Tabel 8}

Hasil Analisis Regresi Linier coefficients

\begin{tabular}{|c|c|c|c|}
\hline \multirow[t]{2}{*}{ Model } & $\begin{array}{l}\text { Unstandardize } \\
\text { d Coefficients }\end{array}$ & $t$ & Sig. \\
\hline & B & & \\
\hline (Constant) & 4.413 & 9.275 & 0.000 \\
\hline $\mathrm{X} 1$ & 0.072 & 0.576 & 0.566 \\
\hline $\mathrm{X} 2$ & -0.067 & -0.532 & 0.596 \\
\hline X3 & -0.272 & -2.105 & 0.038 \\
\hline $\mathrm{X} 4$ & -0.010 & -0.089 & 0.929 \\
\hline$\times 5$ & -0.096 & -0.987 & 0.326 \\
\hline
\end{tabular}

Sumber : Hasil pengolahan data dengan SPSS versi 22

Berdasarkan tabel diatas, hasil analisis regresi berganda menghasilkan koefisien untuk variabel bebas yaitu $\mathrm{X}_{1}=$ $0.072 ; X_{2}=-0.067 ; X_{3}=-0.272 ; X_{4}=-$ $0.010 ;$ dan $X_{5}=-.0 .096$ dengan konstanta 4.413. Dengan demikian, dapat dihasilkan persamaan regresi berganda sebagai berikut:

$$
Y=4.413+0.072 X 1-0.067 \times 2-
$$

$0.272 X 3+-0.010 X 4-0.096 Y+e$ 
Persamaan regresi berganda diatas memiliki makna sebagai berikut:
a. Konstanta
(a) sebesar
4.413
mengartikan apabila keadilan
perpajakan, system perpajakan, pemahaman perpajakan, tarif perpajakan dan sanksi perpajakan bernilai 0 , maka penggelapan pajak akan bernilai 4.413 .

b. Koefisien regresi keadilan perpajakan $\left(X_{1}\right)$ sebesar 0.072 , mengartikan bahwa jika keadilan perpajakan mengalami peningkatan satu satuan, maka penggelapan pajak juga akan mengalami peningkatan sebesar 0.072 satuan.

c. Koefisien regresi sistem perpajakan $\left(\mathrm{X}_{2}\right)$ sebesar -0.067, mengartikan jika sistem perpajakan mengalami penurunan satu satuan, maka penggelapan pajak akan mengalami peningkatan sebesar 0.067 .

d. Koefisien regresi pemahaman perpajakan $\left(X_{3}\right)$ sebesar -0.272 , mengartikan bahwa jika pemahaman perpajakan mengalami penurunan satu satuan, maka penggelapan pajak akan mengalami peningkatan sebesar 0.272 .

e. Koefisien regresi tarif perpajakan $\left(\mathrm{X}_{4}\right)$ sebesar -0.010, mengartikan bahwa jika tarif perpajakan mengalami penurunan satu satuan, maka penggelapan pajak akan mengalami peningkatan sebesar 0.010 satuan.

f. Koefisien regresi sanksi perpajakan $\left(X_{5}\right)$ sebesar -.0.096, mengartikan bahwa jika sanksi perpajakan mengalami penurunan satu satuan, maka penggelapan pajak akan mengalami peningkatan sebesar 0.096 .

\section{Hasil Uji Hipotesis}

Pengujian hipotesis dalam penelitian ini terdiri dari tiga cara yaitu koefisien determinan $\left(R^{2}\right)$, uji simultan (uji $\mathrm{F}$ ), dan uji parsial (uji t), berikut adalah penjelasan dari masing-masing pengujian hipotesis:

a. Koefisien Determinan $\left(\mathrm{R}^{2}\right)$
Koefisien determinan $\left(\mathrm{R}^{2}\right)$ mencerminkan seberapa besar variabel independen mempengaruhi variabel dependen. Berdasarkan tabel hasil koefisien determinan $\left(\mathrm{R}^{2}\right)$ dibawah ini menunjukan bahwa nilai Adjusted $R$ Square adalah sebesar 0.125 yang menandakan bahwa variabel independen hanya $12 \%$ mempengaruhi variabel dependen, dan sisanya yaitu sebesar $82 \%$ pengaruh berasal dari faktor lain. Berikut ini adalah tabel hasil koefisien determinan $\left(R^{2}\right)$ :

\section{Tabel 9}

Hasil Koefisien Determinan $\left(\mathbf{R}^{2}\right)$

\begin{tabular}{|c|c|c|c|}
\hline Model & $\mathrm{R}$ & $\begin{array}{c}\mathrm{R} \\
\text { Square }\end{array}$ & $\begin{array}{c}\text { Adjuste } \\
\mathrm{d} R \\
\text { Square }\end{array}$ \\
\hline 1 & & & \\
\hline 1 & $0.407^{\mathrm{a}}$ & 0.166 & 0.125 \\
\hline
\end{tabular}

Sumber : hasil pengolahan data dengan SPSS versi 22

b. Uji Simultan (uji F)

Pengujian ini bertujuan untuk mengetahui ada tidaknya pengaruh antara variabel independen $(X)$ dan variabel dependen (Y) secara simultan. Berdasarkan tabel 4.15 dibawah ini menunjukan bahwa nilai signifikan adalah sebesar 0.002 dimana nilai tersebut kurang dari 0.05 $(<0.05)$, hal tersebut menandakan bahwa varibel independen yang terdiri dari variabel keadilan perpajakan, sistem perpajakan, pemahaman perpajakan, tarif perpajakan, dan sanksi perpajakan berpengaruh terhadap variabel dependen yaitu penggelapan pajak. Berikut ini adalah hasil uji simultan dari semua variabel independen terhadap variabel dependen :

Tabel 10

Hasil Uji Simultan

\begin{tabular}{|l|c|c|}
\hline Model & $\mathrm{F}$ & Sig. \\
\hline Regression & 4.126 & $.002^{\mathrm{b}}$ \\
\hline
\end{tabular}




\begin{tabular}{|l|l|l|}
\hline Residual & & \\
\hline Total & & \\
\hline
\end{tabular}

Sumber : hasil pengolahan data dengan SPSS versi 22

\section{c. Uji Parsial (Uji T)}

Pengujian ini bertujuan untuk mengetahui pengaruh dari variabel independen $(X)$ terhadap variabel dependen ( $Y$ ) secara parsial. Dibawah ini adalah hasil uji t dari masing-masing variabel:

\section{Tabel 11}

Hasil Uji Parsial (Uji t)

\begin{tabular}{|c|c|c|c|}
\hline \multirow{2}{*}{ Model } & $\begin{array}{c}\text { Unstan } \\
\text { dardize } \\
\mathrm{d} \\
\text { Coeffici } \\
\text { ents } \\
\text { B }\end{array}$ & $\mathrm{t}$ & Sig. \\
\hline $\begin{array}{c}\text { (Constant } \\
\text { ) }\end{array}$ & 4.413 & 9.275 & 0.000 \\
\hline $\mathrm{X} 1$ & 0.072 & 0.576 & 0.566 \\
\hline $\mathrm{X} 2$ & -0.067 & -0.532 & 0.596 \\
\hline $\mathrm{X} 3$ & -0.272 & -2.105 & 0.038 \\
\hline $\mathrm{X} 4$ & -0.010 & -0.089 & 0.929 \\
\hline X5 & -0.096 & -0.987 & 0.326 \\
\hline \multicolumn{3}{|c|}{ Sumber Hasil pengolahan data } \\
dengan SPSS versi 22
\end{tabular}

Berdasarkan hasil uji parsial (uji t) pada masing-masing variabel, didapatkan hasil bahwa satu dari lima variabel independen berpengaruh pada variabel dependen dengan batas minimum koefisien korelasi sig (p) 0.05 .

a. Hipotesis pertama $(\mathrm{H} 1)$

Variabel keadilan perpajakan $\left(\mathrm{X}_{1}\right)$ memiliki nilai signifikan sebesar 0.566 dimana nilai tersebut lebih dari 0.05 $(>0.05)$, ini menunjukan bahwa variabel keadilan perpajakan tidak berpengaruh terhadap penggelapan pajak. Maka dari itu hipotesis pertama $(\mathrm{H} 1)$ ditolak karena variabel keadilan perpajakan tidak berpengaruh terhadap penggelapan pajak.

b. Hipotesis kedua $(\mathrm{H} 2)$

Variabel sistem perpajakan $\left(\mathrm{X}_{2}\right)$ memiliki nilai signifikan sebesar 0.596 dimana nilai tersebut lebih dari 0.05 $(>0.05)$, ini menunjukan bahwa variabel sistem perpajakan tidak berpengaruh terhadap penggelapan pajak. Dengan demikian hipotesis kedua (H2) ditolak karena variabel sistem perpajakan tidak berpengaruh terhadap penggelapan pajak.

c. Hipotesis ketiga $(\mathrm{H} 3)$

Variabel pemahaman perpajakan $\left(\mathrm{X}_{3}\right)$ memiliki nilai signifikan sebesar 0.038 dimana nilai tersebut kurang dari 0.05 $(<0.05)$ dan bertanda negatif $(-)$, ini menunjukan bahwa variabel pemahaman perpajakan berpengaruh secara negatif terhadap penggelapan pajak. Oleh sebab itu hipotesis ketiga $(\mathrm{H} 3)$ diterima karena variabel pemahaman perpajakan berpengaruh negatif terhadap penggelapan pajak.

c. Hipotesis keempat $(\mathrm{H} 4)$

Variabel tarif perpajakan $\left(\mathrm{X}_{4}\right)$ memiliki nilai signifikan sebesar 0.929 dimana nilai tersebut lebih dari $0.05 \quad(>0.05)$, ini menunjukan bahwa variabel tarif perpajakan tidak berpengaruh terhadap penggelapan pajak. Dengan demikian hipotesis keempat $(\mathrm{H} 4)$ ditolak karena variabel tarif perpajakan tidak berpengaruh terhadap penggelapan pajak.

d. Hipotesis kelima (H5)

Variabel sanksi perpajakan $\left(\mathrm{X}_{5}\right)$ memiliki nilai signifikan sebesar 0.326 dimana nilai tersebut lebih dari 0.05 (>0.05), ini menunjukan bahwa variabel sanksi perpajakan tidak berpengaruh terhadap penggelapan pajak. Dengan demikian hipotesis kelima (H5) ditolak karena variabel sanksi perpajakan tidak berpengaruh terhadap penggelapan pajak.

\section{Pembahasan \\ Pengaruh Keadilan Perpajakan Terhadap Penggelapan Pajak}

Hasil pengujian secara parsial variabel keadilan pajak tidak berpengaruh terhadap penggelapan pajak, ini dapat dilihat dari besarnya nilai Sig untuk variabel keadilan pajak menunjukkan nilai signifikansi sebesar 0,556 dan t hitung 0.576 , nilai tersebut lebih besar dari 0.05 (Sig. >0.05) dan koefisien regresi memiliki tanda positif $(+)$, maka $\mathrm{H} 1$ ditolak,artinya 
keadilan pajak tidak berpengaruh terhadap penggelapan pajak.

Penelitian ini belum berhasil menenukan bukti pengaruh antara variabel keadilan terhadap pengggelapan pajak. Hal ini tidak sesuai dengan theory of planned behavior dan penelitian dari Yezzie (2017) yang menjelaskan semakin tinggi tingkat keadilan maka tindakan penggelapan pajak dianggap tidak etis. Namun hasil penelitian ini tidak sesuai dengan penelitian terdahulu karena ada atau tidaknya keadilan perpajakan tidak mempengaruhi persepsi wajib pajak untuk melakukan atau tidak melakukan tindakan penggelapan pajak. Pernyataan ini diperkuat dengan hasil analisis deskriptif jawaban responden yang mayoritas responden setuju bahwa secara umum keadilan dalam perpajakan pada Dirjen pajak khususnya KPP Pratama Subang sudah adil.

$\mathrm{Hal}$ ini diperkuat oleh penelitian Marlina (2018) dan Ardi (2016) yang mengatakan bahwa keadilan perpajakan tidak berpengaruh terhadap penggelapan pajak. hal ini juga didukung oleh penelitian yang dilakukan oleh Sari (2015) bahwa keadilan pajak tidak terdapat pengaruhnya terhadap penggelapan pajak. Berbanding terbalik dengan hasil penelitian yang dilakukan oleh Yuliyanti dkk (2017), zainab (2017) dan (In \& Java, 2018).

\section{Pengaruh Sistem Perpajakan Terhadap Penggelapan Pajak}

Hasil pengujian secara parsial variabel sistem pajak tidak berpengaruh terhadap penggelapan pajak, ini dapat dilihat dari besarnya nilai Sig untuk variabel sistem pajak menunjukkan nilai signifikansi sebesar 0,596 dan t hitung 0.532 , nilai tersebut lebih besar dari 0.05 (Sig. >0.05), maka H2 ditolak, artinya sistem pajak tidak berpengaruh terhadap penggelapan pajak.

Penelitian ini belum berhasil menemukan bukti adanya pengaruh antara sistem perpajakan terhadap penggelapan pajak serta tidak sesuai dengan theory of planned behavior. Hal ini menunjukan bahwa baik atau buruknya sistem perpajakan yang berlaku tidak mempengaruhi persepsi wajib pajak untuk melakukan atau tidak melakukan penggelapan pajak. Dari jawaban responden yang sudah terkumpul menunjukan bahwa mereka telah merasakan kemudahan sistem perpajakan yang telah di berlakukan berdasarkan undang-undang namun baik tidaknya sistem perpajakan yang berlaku tidak mempengaruhi wajib pajak untuk melakukan penggelapan pajak. Hasil penelitian ini dibuktikan oleh Fatimah dan Wardani (2017) serta penelitian Felicia (2017) yang menyimpulkan bahwa sistem perpajakan tidak berpengaruh terhadap penggelapan pajak.

Hal ini sejalan dengan hasil penelitian Yuliyanti dkk (2017) yang menyebutkan bahwa sistem perpajakan tidak berpengaruh terhadap persepsi penggelapan pajak badan. Dengan demikian hasil penelitian ini berbanding terbalik dengan hasil penelitian Yezzie (2017), Ismarita (2018) Marlina (2018) serta Tri (2017).

\section{Pengaruh Pemahaman Perpajakan Terhadap Penggelapan Pajak}

Hasil pengujian secara parsial variabel pemahaman perpajakan berpengaruh negatif terhadap penggelapan pajak. Ini dapat dilihat dari besarnya nilai t hitung sebesar -2.105 dan untuk variabel pemahaman perpajakan menunjukkan angka Sig $<0,05$ yaitu 0.038 dengan koefisien regresi memiliki tanda negatif (-), artinya $\mathrm{H} 3$ ditolak.

Hal ini membuktikan bahwa semakin wajib pajak yang tidak memahami peraturan perpajakan secara jelas maka akan cenderung menjadi wajib pajak yang tidak taat. Hal ini sesuai dengan Theory of planned behavior serta penelitian ini sejalan dengan penelitian Rahmadi dan Zulaikha (2014) yang menyebutkan bahwa pemahaman perpajakan menunjukkan adanya indikasi nilai yang negatif. Hal ini mengindikasikan bahwa semakin wajib pajak memahami aturan, tata cara, tentang ketentuan perpajakan ketika melakukan kewajiban perpajakan maka perilaku penggelapan pajak dipandang tidak etis untuk dilakukan. 
Hasil penelitian ini didukung oleh hasil penelitian Yulia dan Hertia (2017) serta Sari (2015) yang menyebutkan bahwa pemahaman perpajakan berpengaruh negatif terhadap penggelapan pajak. Akan tetapi hasil penelitian ini tidak sejalan dengan penelitian Marlina (2018) yang mengatakan bahwa pemahaman perpajakan berpengaruh positif signifikan terhadap penggelapan pajak. Hasil penelitian ini membuktikan bahwa semakin tinggi pengetahuan dan pemahaman wajib pajak akan perpajakan maka semakin tinggi peluang melakukan penggelapan pajak, artinya wajib pajak memanfaatkan pengetahuan dan pemahaman yang dimiliki guna melakukan penggelapan pajak.

\section{Pengaruh Tarif Perpajakan Terhadap Penggelapan Pajak}

Hasil pengujian secara parsial variabel tarif perpajakan tidak berpengaruh terhadap penggelapan pajak. Ini dapat dilihat dari besarnya nilai thitung sebesar -0.089 dan untuk variabel pemahaman perpajakan menunjukkan angka Sig > 0,05 yaitu 0.929 ini artinya $\mathrm{H} 4$ ditolak.

Penelitian ini belum berhasil menemukan adanya hubungan atau pengaruh tarif perpajakan terhadap penggelapan pajak. Hal ini tidak sesuai dengan theory of planned behavior berdasarkan jawaban yang telah diperoleh dari seluruh responden, menunjukan bahwa tarif yang berlaku sudah sesuai dengan kemampuan wajib pajak namun hal tersebut tidak mempengaruhi mereka untuk melakukan atau tidak melakukan penggelapan pajak.

Menurut Sasmito (2017) Perilaku penggelapan pajak tersebut dapat disebabkan karena wajib pajak mengetahui celah-celah peraturan perpajakan dan kemampuannya dalam menyembunyikan objek pajak sehingga tidak diketahui oleh pihak fiskus saat pemeriksaan ini terbukti dari hasil penelitiannya yang menunjukkan bahwa variabel tarif pajak secara signifikan tidak memiliki pengaruh terhadap penggelapan pajak. Kesimpulan tersebut berdasarkan hubungan bahwa ketika tarif pajak yang harus dibayarkan oleh wajib pajak tersebut tinggi, maka dapat menyebabkan tindakan penggelapan pajak. Namun pada kenyataannya wajib pajak akan tetap melakukan tindakan penggelapan pajak meskipun tarif pajak yang dikenakan sesuai dengan tingkat penghasilan mereka atau bahkan tarifnya lebih rendah.

Hasil ini relevan dengan penelitian Yuliyanti dkk (2017) yang menyimpulkan bahwa tarif pajak tidak berpengaruh terhadap persepsi penggelapan pajak badan. Namun hasil penelitian ini tidak relevan dengan penelitian Felicia (2017) Kurniawan dan Toly (2014) serta Tri (2017).

\section{Pengaruh Sanksi Perpajakan Terhadap Penggelapan Pajak}

Hasil pengujian secara parsial variabel sanksi perpajakan tidak berpengaruh terhadap penggelapan pajak. Ini dapat dilihat dari besarnya nilai thitung sebesar -0.987 dan untuk variabel pemahaman perpajakan menunjukkan angka Sig $>0,05$ yaitu 0.326 ini artinya $\mathrm{H} 5$ ditolak.

Penelitian ini belum berhasil menemukan pengaruh atau hubungan sanksi perpajakan terhadap penggelapan pajak dan tidak sesuai theory of planned behavior. Berdasarkan perolehan jawaban dari semua responden menunjukan bahwa penerapan sanksi sudah sesuai dengan undang-undang yang berlaku serta sanksi telah diterapkan secara tegas kepada wajib pajak yang melanggar namun penerapan tegas atau tidaknya sanksi tidak mempengaruhi wajib pajak dalam melakukan atau tidak melakukan penggelapan pajak.

Hal ini relevan dengan penelitian Yezzie (2017) yang menyimpulkan bahwa sanksi perpajakan tidak berpengaruh terhadap penggelapan pajak. Hal ini didukung oleh Rachmadi (2014) semakin besar denda yang dibebankan kepada wajib pajak akan mendorong Wajib Pajak untuk berperilaku tidak patuh dan semakin banyak kesempatan yang dimiliki Wajib Pajak untuk melakukan penggelapan 
pajak. Hal ini menunjukkan bahwa pengenaan sanksi kepada pelanggar peraturan perpajakan tidak memberikan pengaruh terhadap persepsi Wajib Pajak dan praktik penggelapan pajak masih terjadi.

Namun hal ini berbanding terbalik dengan hasil penelitian Felicia (2017) dan Yuliyanti dkk (2017) serta penelitian Yulia dan Hertia (2017).

\section{Pengaruh Keadilan, Sistem, Pemahaman, Tarif dan Sanksi Perpajakan Terhadap Penggelapan Pajak}

Berdasarkan uji statistik yang telah dilakukan menunjukan adanya pengaruh keadilan perpajakan, sistem perpajakan, pemahaman perpajakan, tarif perpajakan dan sanksi perpajakan terhadap penggelapan pajak hal ini terlihat dari dari hasil statistik uji regresi yang menunjukan bahwa nilai sig. F adalah 0.002 dimana nilai tersebut kurang dari 0.05 (sig. <0.05) yang berarti kelima variabel tersebut secara simultan berpengaruh terhadap variabel dependen. Akan tetapi berdasarkan nilai Adjusted $R$ Square $\left(\mathrm{R}^{2}\right)$ sebesar 0.125 yang menandakan bahwa pengaruh kelima variabel independen terhadap variabel dependen hanya sebesar $12 \%$, dan sisanya yaitu sebesar $88 \%$ bisa jadi berasal dari faktor lain yang tidak diteliti pada penelitian ini. Dari hasil tersebut menunjukan bahwa hipotesis keenam $\left(\mathrm{H}_{6}\right)$ dalam penelitian ini diterima yang menyatakan bahwa keadilan perpajakan, sistem perpajakan, pemahaman perpajakan, tarif perpajakan dan sanksi perpajakan berpengaruh terhadap penggelapan.

\section{KESIMPULAN}

Penelitian ini bertujuan untuk mengetahui pengaruh keadilan perpajakan, sistem perpajakan, pemahaman perpajakan, tarif perpajakan dan sanksi perpajakan terhadap penggelapan pajak. Berdasarkan hasil perhitungan menggunakan SPSS versi 22 dapat ditarik kesimpulan sebagai berikut :
1. Keadilan perpajakan tidak berpengaruh terhadap penggelapan pajak. Ada atau tidaknya keadilan perpajakan tidak mempengaruhi persepsi wajib pajak untuk melakukan atau tidak melakuakn tindakan penggelapan pajak.

2. Sistem perpajakan tidak berpengaruh terhadap penggelapan pajak. Hal ini menunjukan bahwa baik atau buruknya sistem perpajakan yang berlaku tidak mempengaruhi persepsi wajib pajak untuk melakukan atau tidak melakukan penggelapan pajak.

3. Pemahaman perpajakan berpengaruh negatif terhadap penggelapan pajak. Hal ini membuktikan bahwa semakin wajib pajak yang tidak memahami peraturan perpajakan secara jelas maka akan cenderung menjadi wajib pajak yang tidak taat sehingga wajib pajak melakukan penggelapan pajak.

4. Tarif perpajakan tidak berpengaruh terhadap penggelapan pajak. Hal ini menunjukan bahwa meskipun penerapan tarif pajak yang berlaku sudah sesuai dengan kemampuan wajib pajak tetapi tidak mempengaruhi wajib pajak dalam melakukan atau tidak melakukan tindakan penggelapan pajak.

5. Sanksi perpajakan tidak berpengaruh terhadap penggelapan pajak. Hal ini menunjukkan bahwa pengenaan sanksi kepada pelanggar peraturan perpajakan tidak memberikan pengaruh terhadap persepsi wajib pajak untuk melakukan atau tidak melakukan praktik penggelapan pajak.

6. Secara simultan keadilan, sistem, pemahaman, tarif dan sanksi perpajakan berpengaruh terhadap penggelapan pajak serta berdasarkan nilai Adjusted $R$ Square $\left(\mathrm{R}^{2}\right)$ menunjukan bahwa adanya pengaruh dari kelima variabel independen terhadap variabel dependen hanya sebesar $12 \%$, dan sisanya yaitu sebesar $88 \%$ yang berasal dari faktor lain yang tidak diteliti dalam penelitian ini.

\section{KETERBATASAN}


Adapun keterbatasan dari penelitian inimadalah sebagai berikut :

1. penelitian ini hanya diteliti pada objek wajib pajak badan sehingga hasil analisis yang diperoleh hanya untuk wajib pajak badan tidak berlaku untuk wajib pajak orang pribadi.

2. Jumlah responden yang didapat hanya berjumlah 110 responden dikarenakan susahnya mencari responden yang dibutuhkan karena data wajib pajak adalah privasi bagi kantor pajak.

3. Kuesioner penelitian ini hanya menggunakan kuesioner sehingga belum menggambarkan kondisi objek penelitian secara utuh.

\section{SARAN}

Berdasarkan hasil kesimpulan, maka peneliti memberikan beberapa saran sebagai berikut:

1. Penelitian lebih lanjut perlu menambahkan variabel yang lebih luas, seperti determinasi terjadinya kecurangan dan intensitas pemeriksaan pajak dan lain-lain. Karena masih banyak faktor yang mempengaruhi penggelapan pajak.

2. Penelitian selanjutnya diharapkan memperluas objek penelitiannya dan menggunakan metode penelitian selain menyebar kuesioner, misalnya wawancara untuk memperoleh hasil penelitian yang lebih mendalam dan lebih baik.

\section{REFERENCES}

\section{Undang-Undang}

Undang- Undang Nomor 28 Tahun 2007

Undang- Undang Nomor 16 Tahun 2009

\section{Buku}

B. Ilyas dan Bruton.2008. Hukum Pajak.Edisi Empat salemba Empat Jakarta.

Ghozali, Imam. (2016). Aplikasi Analisis Multivariete dengan Program IBM SPSS 23. Edisi
VIII. Badan Penerbit Universitas Diponogoro. Semarang.

Mardiasmo.2016. Perpajakan. Edisi terbaru 2016 Andi Yogyakarta.

Resmi, Siti.2017. Perpajakan Teori dan Kasus. Edisi Sepuluh Salemba Empat Jakarta.

Sekaran dan Bougie.2017. Metode Penelitian untuk Bisnis.Edisi Enam Salemba Empat Jakarta.

Sugiyono. (2018). Metode Penelitian

Bisnis. Penerbit Alpabeta.

Bandung

Sugiyono.2015. Metode Penelitian Kombinasi(Mixed methods.

Alfabeta Bandung.

Waluyo dan B. Ilyas.2002. Perpajakan Indonesia. Edisi Pertama Salemba Empat Jakarta.

\section{Sumber Skripsi Dan Jurnal}

Ameyaw, B., \& Dzaka, D. (2016). Determinants of Tax Evasion: Empirical Evidence from Ghana. Modern Economy, 07(14), 16531664.

https://doi.org/10.4236/me.2016.7 14145

Barth, E., \& Ognedal, T. (2018). Tax Evasion in Firms. Labour, 32(1), 23-44.

https://doi.org/10.1111/labr.12111

Bekoe, W., Nketiah-Amponsah, E., \& Annan, B. (2018). Determinants of Tax Evasion in Ghana. International Journal of Economic Sciences and Applied Research 6 (3): 97-121, 6(3), 97-121.

Drogalas, G., Anagnostopoulou, E., Pazarskis, M., \& Petkopoulos, D. (2018). Tax Ethics and Tax Evasion, Evidence from Greece. Theoretical Economics Letters, 08(05), 1018-1027. https://doi.org/10.4236/tel.2018.8 5070

Fatimah dan wardani.2017.FaktorFaktor Yang Mempengaruhi 
Penggelapan Pajak Di Kantor Prlayanan Pajak Pratama Temanggung. Akuntansi Dewantara :Vol. 1 No. 1 April 2017.

Fatimah, Tri (2017). Pengaruh Sistem Perpajakan, Tarif Pajak Dan Kualitas Pelayanan Fiskus Terhadap Persepsi Wajib Pajak Mengenai Penggelapan Pajak (Studi Kasus pada KPP Pratama Jakarta Cengkareng). Skripsi. Diterbitkan. Universitas Mercu Buana jakarta.

Felicia, I. (2017). Pengaruh Sistem Perpajakan, Sanksi Perpajakan Dan Tarif Pajak Terhadap Persepsi Wajib Pajak Mengenai Etika Penggelapan Pajak (Study Kasus Di Daerah Istimewa Yogyakarta), 25(2), 226-234.

Haddidi, E. Al. (2017). Tax Evasion in Jordan: Reality, Causes and Results Tax Evasion in Jordan: Reality, Causes and Results, (July).

In, C., \& Java, W. (2018). RJOAS, 1(73), January 2018, 1(January), 163-170.

Ismarita, Gusmella.(2018). Pengaruh Keadilan, Tarif Pajak, Teknologi Dan Informasi, Deskriminasi Dan Sistem Perpajakan Terhadap Penggelapan Pajak (Studi Kasus pada WPOP Pedagan Eceran di KPP Pratama Rengat). Fakultas Ekonomi. Universitas Riau : Vol. 1 Edisi. 1 (2018).

Kiri, N. (2016). Factors Affecting Tax Evasion. International Journal of Economics, Commerce and Management United Kingdom, IV(2), 804-811. Retrieved from http://ijecm.co.uk/

Kurniawati, M., \& Toly, A. A. (2014). Analisis Keadilan Pajak, Biaya Kepatuhan, Dan Tarif Pajak Terhadap Persepsi Wajib Pajak
Mengenai Penggelapan Pajak Di Surabaya Barat. Tax \& Accounting Review, 4(2), 1-12.

Lanka, S. (2018). Modeling Tax Evasion across South Asia: Evidence from Murshed \& Saadat, 8(1), 15-32.

Marlina. (2018). Analisis Faktor-Faktor Yang Mempengaruhi Persepsi Wajib Pajak Orang Pribadi Mengenai Penggelapan Pajak ( Studi Empiris pada KPP Pratama Lubuk Pakam ), 02(02), 151-168.

Mashita, Zainab. (2017) Pengaruh sistem Perpajakan, Deskriminasi Perpajakan, Teknologi dan Informasi Perpajakan, Keadilan Perpajakan Terhadap Etika Penggelapan Pajak. (Studi Empiris pada KPP Pratama Kecamatan Gayamsari kota semarang). Undergraduate Thesis. Fakultas Ekonomi.UNISSULA.

McGee, R., \& Shopovski, J. (2018). the Ethics of Tax Evasion: a Survey of Law and Economics Students in the Republic of Macedonia. International Journal of Economic Sciences, VII(2), 57-69. https://doi.org/10.20472/ES.2018. 7.2.003

Pajak, E. P., Empiris, S., Orang, P., \& Kota, W. (2017). Pengaruh sistem perpajakan, diskriminasi, kepatuhan dan pengetahuan perpajakan terhadap persepsi wajib pajak mengenai etika penggelapan pajak, 2045-2059.

Pulungan, R. H. (2015). Pengaruh keadilan, sistem perpajakan, dan kemungkinan terdeteksinya kecurangan terhadap persepsi wajib pajak mengenai etika penggelapan pajak (tax evasion), 2(1), 1-14. https://doi.org/10.1186/17520509-2-36 
Rachmadi, W., \& Zulaikha. (2014). Faktor-Faktor yang Mempengaruhi Persepsi Wajib Pajak Orang Pribadi Atas Perilaku Penggelapan Pajak. Diponegoro Journal of Accounting, 3(2), 1-9.

Sari, M.T.(2015). Pengaruh Keadilan, Self Assessment System, Diskriminasi, Pemahaman Perpajakan, Pelayanan Aparat Pajak, Dan Kemungkinan Terdeteksi Kecurangan Terhadap Tindakan Tax Evasion (Studi Kasus pada KPP Pratama Semarang Candisari) Skripsi. Diterbitkan. Fakultas Ekonomi. Universitas Negeri Semarang.

Wahyuni, M. A. (2019). The Examination of Tax Evasion Behavior of Tax Payers from The Perspective of Planned Behavior Theory, 69(Teams 2018), 45-51.

Yezzie, Christine.2017. Pengaruh Keadilan, Sistem Perpajakan, Pemahaman Perpajakan Dan Sanksi Pajak Terhadap Persepsi Wajib Pajak Mengenai Etika Penggelapan Pajak (Tax Evasion). Skripsi. Diterbitkan. Fakultas Ekonomi Dan Bisnis. Universitas Lampung : Bandarlampung.

Yulia, R., \& Hertia. (2017). Analisis Pengaruh Keadilan Perpajakan, Sistem Perpajakan, Pemahaman Perpajakan Dan Sanksi Perpajakan Terhadap Persepsi Pajak Mengenai Perilaku Penggelapan Pajak (Tax Evasion) Di Kpp Pratama Teluk Betung, 1(1), 72-86.

Yuliyanti, T., Titisari, H. K., \& Nurlela, S. (2017). Seminar Nasional IENACO - 2016 ISSN : 2337 4349 Seminar Nasional IENACO -
2016 ISSN : 2337 - 4349. Seminar Nasional IENACO, 541-548. https://doi.org/10.1029/2008JF00 1135

\section{Sumber Website}

https://tirto.id/delapan-strategi-

menkeu-tingkatkan-penerimaan-pajakcsXZ

https://www.liputan6.com/bisnis/read/3 636523/penerimaan-pajak-capai-rp79947-triliun-per-31-agustus-2018 https://www.suara.com/bisnis/2017/11/ 30/190456/fitra-setiap-tahunpenghindaran-pajak-capai-rp110triliun

https://nasional.tempo.co/read/1054384/ke jaksaan-agung-tangkap-buronpenggelapan-pajak-rp-1068-miliar

http://mediaindonesia.com/read/detail/122 136-kasus-penggelapan-pajak-miliaranrupiah-di-medan-mulai-disidangkan

https://www.suara.com/partner/content/po rtalsatu/2018/10/19/065517/djp-acehserahkan-tersangka-kasus-penggelapanpajak-kepada-kejaksaan-portalsatucom

http://www.pendidikanekonomi.com/2014 /08/teori-perilaku-yang-direncanakantheory.html

http://repository.usu.ac.id/bitstream/handl e/123456789/43562/Chapter\%20II.pdf?se quence $=4 \&$ isAllowed $=y$

http://indahjewel.blogspot.com/2012/06/m akalah-wajib-pajak-wp-badan.html 